\title{
熊本市上江津湖の地下水環境に関する研究 一国指定天然記念物スイゼンジノリの自生環境保護を対象として一
}

\author{
荒牧昭二郎*・金子好 雄*・市川＼cjkstart勉*・岡 本 智 伸**・椛 田 聖 孝**
}

\begin{abstract}
要 旨
近年, 自生スイゼンジノリが都市開発に伴う涌水量の減少と水質の悪化により絶滅の危機に直面している，この研究は，電気探査によ る比抵抗映像解析や地盤情報データベースを用いた地層区分図, 涌水量や水質を調べ, 天然記念物スイゼンジノリ環境保護の基礎デー夕 を得るための総合的研究である. 調査の結果, 江津湖の 1 日の湧水量は約 40 万 $\mathrm{m}^{3}$ であり, 湧水量は 7 年間で $10 \%$ 程度減少していること, 江津湖の涌水は最上部の水脈之砥川溶岩上部と下部の 3 つの地下水脈が存在すること, 砥川溶岩中の地下水とその上の地下水は江津湖付 近で一緒になり水質が混在していること，スイゼンジノリ自生地の水質は他の湧水池に比べてアルミニウムが少なく清純であり，その地 下水は砥川溶岩の下の地下水から供給されている可能性が高いことがわかった.
\end{abstract}

Key words：スイゼンジノリ Suizenjinori, 地下水 groundwater, 比抵抗影像法 resistivity image profiling, 水質調査 water examination

\section{1. は じめに}

スイゼンジノリは世界で熊本市の上江津湖のみにしか自 生しない淡水産ラン藻の一種で, オランダの植物学者, ス リンガーが本種を1824(明治 5)年に始めて生物学的に分類 し新属新種のラン藻として, 学名をPhyloderma Sacrum Suringarと名付けて世界に紹介した。 その後, 1953(昭和 28)年, 岡田喜一は, これが水田に生えるハマミドリと同 属であるとして, 学名をAphanothece Sacrum(Sur.) Okada と改め現在に至っている ${ }^{1)}$.

ラン藻とは，原核生物で細胞に核はなく，DNA分子が ほとんぞ裸のまま細胞の中央部に存在している生物である. 今から約30～25億年前の先カンブリア時代に海の中におい て発生し, その後大繁殖して, 光合成を行い, 地球環境に 最初の酸素をあたらした生物である. 多数のマユ形の単細 胞が寒天質の中に埋没する状態で群体を形成し, 清澄な水 で浮いたり沈んだりして生息する特異な生理・生態により, 発生地の一つである熊本市出水神社境内(上江津湖の一部) が1924(大正13)年に国の天然記念物に指定された。昭和 28 年の大水害により絶滅の危機に直面したが, 関係諸団体や

*九州東海大学工学部 School of Engineering, Kyushu Tokai University

**九州東海大学農学部 School of Agriculture, Kyushu Tokai University
地元ボランティアの努力によりかなりの回復が見られた. しかし，熊本地域では都市開発に伴い水田，畑地，草地な どの涵養域が昭和 40 年から平成 3 年の間に約 $10 \%$ 減少する など江津湖周辺の湧水の減少と肥料や生活用水の混入によ る水質の変化, それに伴う珪藻類や緑藻類などの増加によ る生態系の变化などで, スイゼンジノリ野生株は急速に減 少し, 1997 (平成 9)年秋, 植物版レッドリスト (環境庁作 成)において，絶滅危惧IA類に分類された。これは，この まま推移すれば，今後10年間に野生絶滅の可能性が50\%以 上であることを示す ${ }^{2) ~ 5)}$.

熊本市は人口約 66 万の上水道をすべて地下水でまかなっ ている世界であ数少ない都市である。その多くの飲み水は, この水前寺・江津湖地区から汲み上げられており, その深 井戸の水の中から発ガン物質である有機溶剂の混入が観測 されている.このように森と水の都の熊本でも, 環境の变 化により湖沼の動植物の減少やスイゼンジノリ絶滅とわれ われの飲料水の危機に直面している．われわれグループは 十年前から上江津湖の湖沼環境について研究し, その結果 を報告 ${ }^{6), 7)}$ してきたが， 湖沼環境は年々悪化の傾向にあり， 湖沼堆積物 (ヘドロ)の堆積の増加と水質の富栄養化が進み, 清水でしか生活できない魚や植物が激減している，この論 文の目的は, 主にスイゼンジノリの絶滅に関連していると 考えられる地下水の湧水機構の解明と湧水量の経年変化, 涌水池の水質特性を調べ，絶滅危惧種のスイゼンジノリを 
保護する基礎デー夕の結果について報告するあのである。

\section{2. 熊本市近傍の地下水の概略}

熊本市を含む阿蘇火山西麓台地には北から木柑子涌水群, 八景水谷湧水群，水前寺・江津湖湧水群や嘉島湧水群が存 在している(図-1 参照)。これらの湧水機構を水理地質的 に最初に解明したのが宮本昇らで，菊地台地付近では花 房層という水成層により旧阿蘇火山噴出物層と新期阿蘇火 山噴出物層とに二分されること，八景水谷湧水群は菊池砂 磎層・託麻砂礫層の自由地下水，木柑子湧水群は旧阿蘇火 山噴出物層の被圧裂罅地下水, 水前寺・江津湖湧水群は託 麻砂㗂層の自由地下水，主として新期阿蘇火山噴出物 (自 由地下水〜被圧地下水)であること，さらに，白川に沿う 撓曲の存在が地下水の帯水層に影響していることを示した。 前者の花房層は難透水層で下位の地下水を加圧する役目を し，熊本市近傍では渡辺・小野的による布田層に対比され る. 後者に述べた撓曲の存在は今西 ${ }^{10)} に よ り$ 明らかにされ ており，地下水盆の難透水層である基盤の地質構造を支配

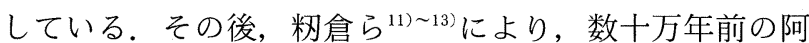
蘇カルデラ形成以前の古地形を示す古加勢川流域が示され， その南半分の涵養域の地下水が八景水谷湧水群，水前寺 江津湖湧水群にきていることを明確にした。この後, 熊本 市水道局 ${ }^{14)}$ や原田・田中 ${ }^{15}$ が水理地質とと屯に熊本市上水 道の状況と地下水利用，地下水流動之涵養源等について報 告し, 熊本県・熊本市 ${ }^{16), 17}$ が地下水流動モデルや地下水保 全について述べている.

\section{3. 国指定スイゼンジノリ近傍の水理地質と地下水}

\section{1 江津湖周辺の地質}

江津湖周辺の地質は下から第三紀の先阿蘇火山岩類，第

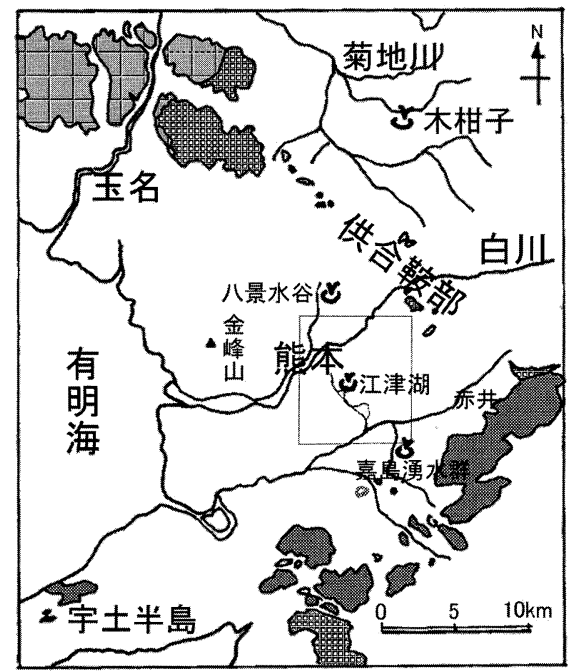

凡例

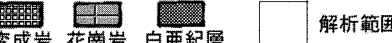

図-1 熊本市周辺の湧水池
表 -1 地質層序

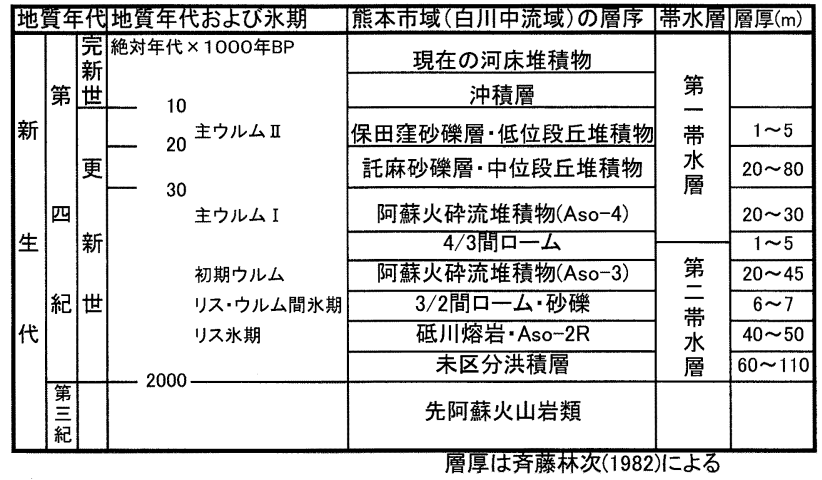

四紀には未区分洪積層, 赤井火口から噴出したと言われて いる砥川溶岩，阿蘇カルデラを形成時に噴出した火砕流堆 積物 (ASO-3，ASO-4) とその間のローム層，更新世の託 麻, 保田洼砂磻層, その上に沖積層之河床堆積物が存在す る. 表-1に地質層序を示す。

熊本地区の帯水層は ASO-3 火研流堆積物之 ASO-4 火砕 流堆積物間の堆積物 $(4 / 3$ 間ローム) の難透水性層を境にし て，上部を「第一帯水層」と下部の「第二帯水層」に区分 される，第一帯水層は主にASO-4 の白色軽石からなる砂 磁〜砂之託麻，保田窪砂磻層の不圧帯水層である。第二帯 水層は砥川溶岩を主にASO-3 の灰〜黒色のスコリアを含 む砂礫層に存在する被圧帯層である。とくに砥川溶岩の下 部之上部には多孔質であるととあに東北東〜西南西の構造 変位による割れ目が多量の地下水を供給しているすのと考 えられる ${ }^{18)}$. 最近では，砥川溶岩の下部に存在する未区分 洪積層からも地下水を取水し, 熊本市の重要な水源となっ ている.

筆者らは熊本市域での地質柱状図を基に地盤情報データ ベースを構築し，砥川溶岩層やASO-3 およびASO-4層, それ之段丘砂礫層の上面標高図を作成した。とくに砥川溶 岩が多量に地下水を包蔵する帯水層となっているので，砥 川溶岩層の上面標高図を図-2 に示す ${ }^{19)}$.

砥川溶岩の分布は図 -1 の中央部の供合鞍部より南西部 に分布し，ほぼ熊本市の市街地の地下に存在する無斑晶緻 密な輝石安山岩であり，砥川溶岩の噴出源は図-1の中央 右に示す赤井地点といわれている。松本 ${ }^{18}$ は，赤井地点に は馬蹄形の丘陵があり溶岩抢よび溶岩流からなる岩滓丘で 溶岩は砥川溶岩之同質であることより砥川溶岩と赤井岩滓 丘双方を合わせたものを赤井火山とした。斎藤201は別の供 給源として図中の中央部より少し右上の京塚付近を火口と する京塚火口(仮称)を提案したが，京塚火口は図中の 2 か 所の連続した起伏部(図中のA)相当するもの之考えられる。 砥川溶岩の上面標高地形は京塚火口と思われる起伏部から 南西部になだらかな傾斜で分布し，熊本市出仲間付近で消 滅している．図中の右下に見られる北東一南西の窪地は木 山一嘉島地溝帯である ${ }^{211}$. 


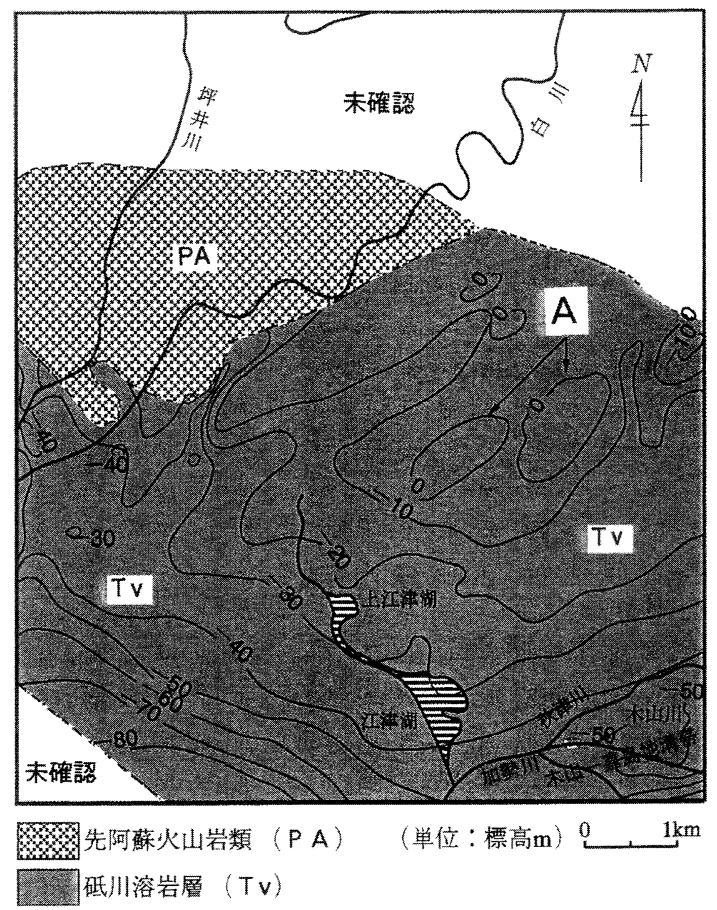

図-2 砥川熔岩上面の標高平面図

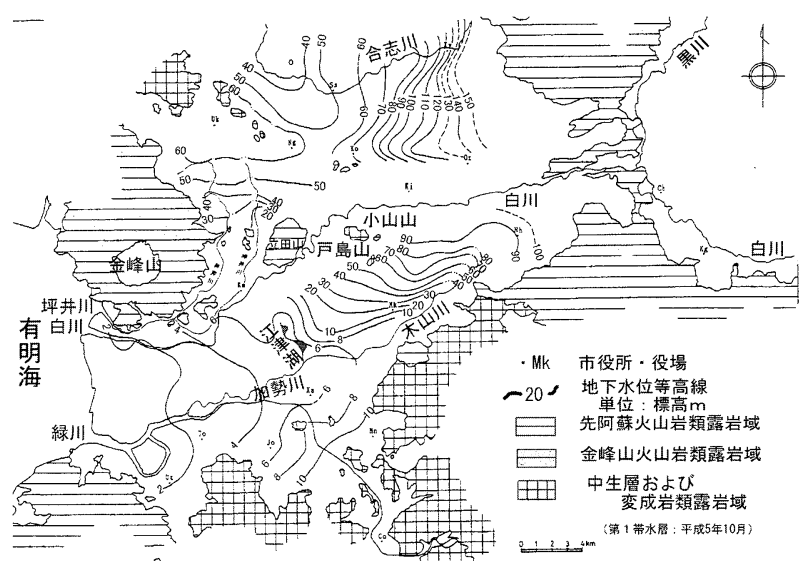

（a）第一帯水層等高線図

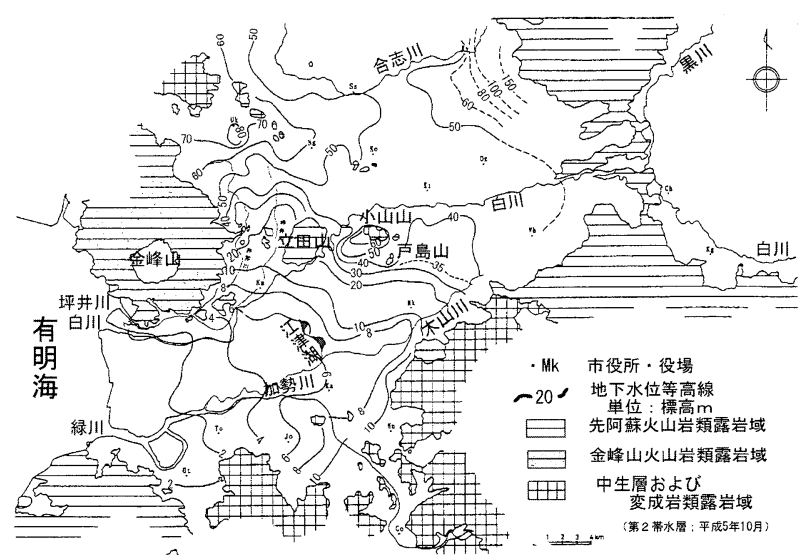

（b）第二帯水層等高線図

図-3 江津湖周辺の地下水位等高線図

\section{2 江津湖周辺の地下水分布}

江津湖周辺の地下水については, 熊本県・熊本市の報告 書 $^{17)}$ で第一帯水層と第二帯水層の地下水位等高線図として

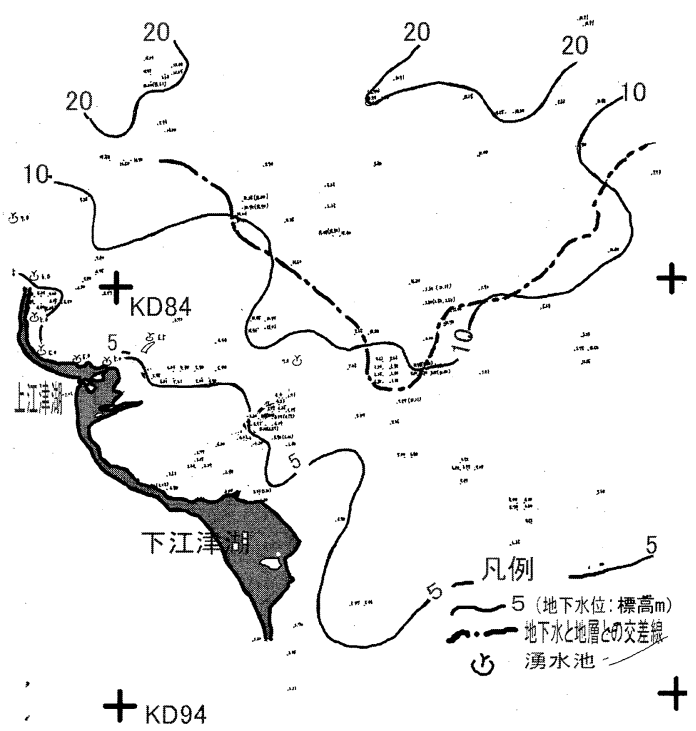

図-4 江津湖周辺の地下水位(第二帯水層)

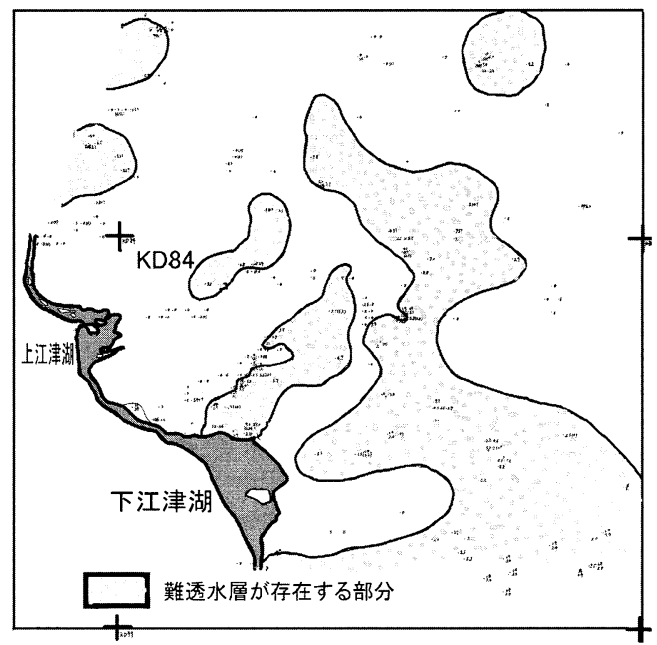

図-5 4/3ロームおよびASO-3火砕流堆積物上面の難透水層の分 布図

示されている(図-3(a), (b)参照)。この図によると, 第一 帯水層と第二帯水層とも白川中流域の地下水が戸島山と木 山川の間を通り江津湖に流れていることを示している. ま た，戸島山と木山川間の地下水位等高線は第一帯水層では 約 $60 \mathrm{~m}$ で第二帯水層の水位は約 $35 \mathrm{~m}$ と違いが明確である が, 江津湖付近(江津湖より北東約 $1 \mathrm{~km}$ 付近, 水位標高 10 m)ではほぼ同じになっている。今回,この付近の地下水 と地質との関係を調べるために，われわれの地盤情報デー タベースにファイルされているボーリングデータから第二 帯水層の地下水位を算出し, それを地図上にプロットした (図-4 参照).

図-4 中の一点破線は第二帯水層の地下水位と ASO-3 火 砕流堆積物の上面 (ASO-4 および $4 / 3$ ロームはぎ取り面) との交差した点を結んだ線である，江津湖北東部には，第 二帯水層の加圧層である布田層(粘土層)が存在しない場所 では,この線より北東の第二帯水層の地下水はASO-3 火 砕流堆積物中に存在し, 逆に南西側の地下水はASO-3 火 
砕流堆積物より上の地層にも地下水が存在することを意味 している。このことは, 一点破線より南側では第一帯水層 の地下水之第二帯水層の地下水が混在して扔り, 地表面環 境に影響を受けやすい第一帯水層の地下水と比較的地表面 環境を受けにくい第二带水層の地下水が混じっている可能 性が高い。従来では, 第一帯水層の地下水之第二帯水層の 地下水との間に難透水性の $4 / 3$ ロームが存在しているた めに第一带水層の地下水の水質にあまり関心が持たれてい なかった。しかし, 図中の一点破線より南側の浅層ボーリ ング(ASO-4 および 4/3 ロームより浅い)の地下水位とそ の近くの深層ボーリング $(\mathrm{ASO}-4$ および $4 / 3$ ロームより深 (）の地下水位とがほぼ同じであること，第一帯水層と第 二带水層間に存在する難透水性の $4 / 3$ ロームおよびASO 3 火砕流堆積物上面の難透水層の層厚を平面上にプロット
した図 (図-5 参照) 中に難透水層の欠如した所が分布して いることから，第二带水層の被圧地下水が第一带水層へ流 れていって両者が混合しているものと考えられる. 安全で おいしい飲料水の確保や江津湖の水生生物のためには第二 带水層の地下水の水量確保とともに第一带水層地下水の水 質がこれ以上悪化しない手立てを講じる必要性を感じる.

\section{4. 比抵抗影像法による涌水機構の解明}

今回, スイゼンジノリ国指定地付近の湧水機構解明のた めに電気探査を行った。測定装置はIRIS社のSyscaljuniorを使い, 電極間隔を $10 \mathrm{~m}$ で 20 電極とし, 市販の RES2DINV解析ソフトで比抵抗影像法 ${ }^{22}$ として解析した。 測線の位置を図 -6 に，その映像を図 $-7,8$ に示す.

図-7 のほぼ中央部がスイゼンジ,リ国指定地であり,

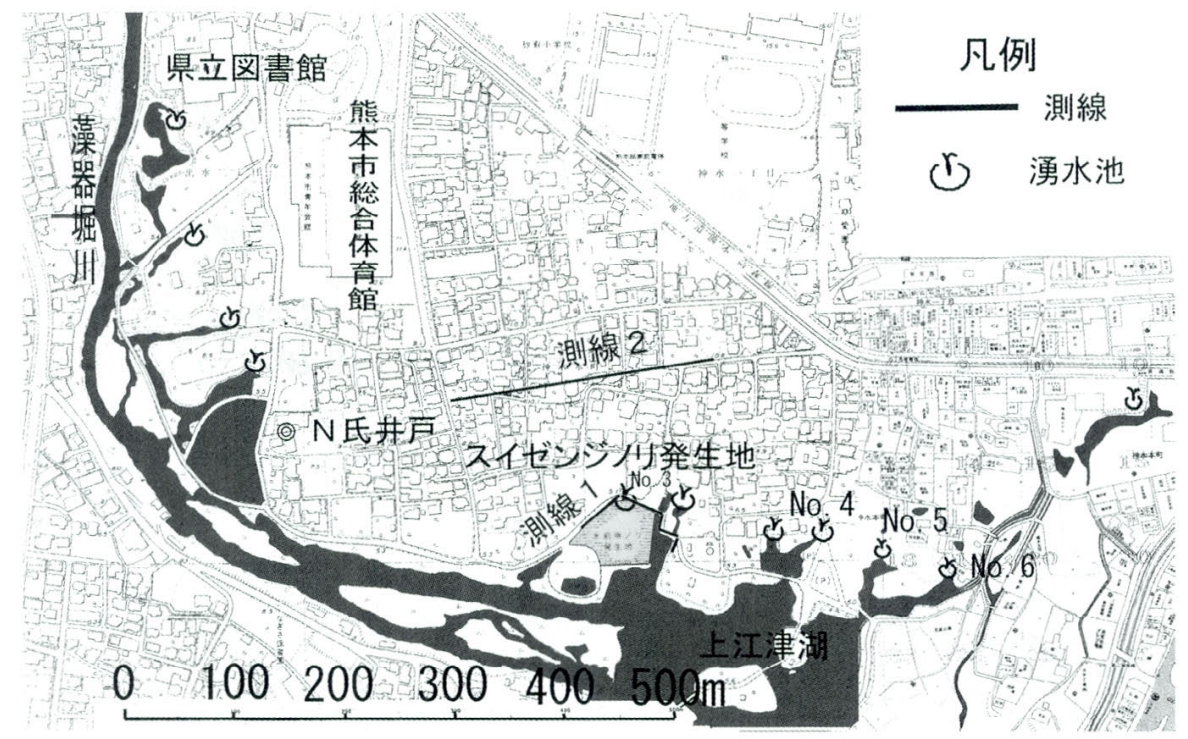

図-6スイゼンジノリ近傍の湧水池と電気探査の測線

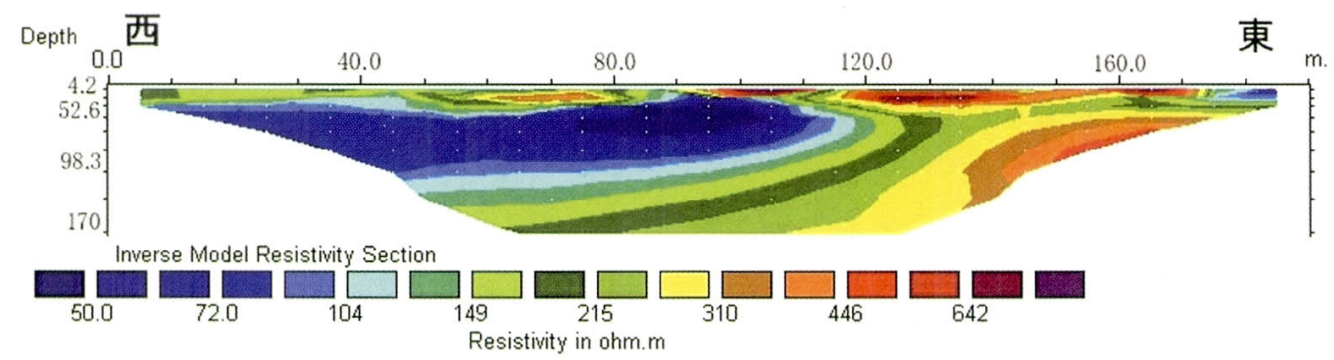

図-7 スイゼンジノリ天然記念物国指定地付近 (測線 1)の電気探查結果 (比抵抗影像法)

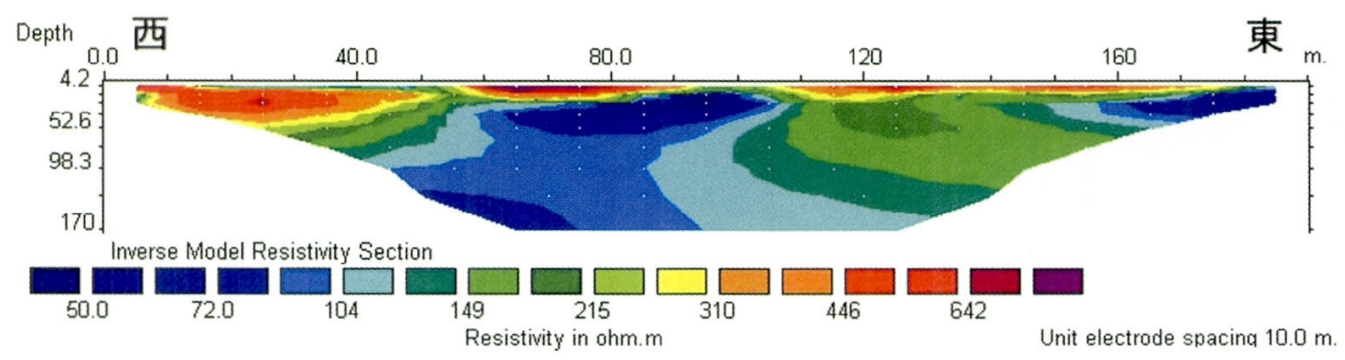

図-8 スイゼンジノリ天然記念物国指定地北側(測線 2)の電気探査結果(比抵抗影像法) 
幅約 $50 \mathrm{~m}$, 深さ約 $40 \mathrm{~m}$ にわたり約 $80 \Omega ・ m$ 程度の低い比 抵抗值の部分が見られる。調查地区での深度約 $35 \sim 80 \mathrm{~m}$ までに砥川溶岩が厚く分布していることょり，この部分の 地質は砥川溶岩と考えられる。熊本市近傍では, 砥川溶岩 の比抵抗值は $50 \sim 10,000 \Omega ・ m$ であり，揚水用ストレイナー は砥川溶岩では $50 \sim 1,000 \Omega ・ m$ の比抵抗值に設置する例 が多いことより, 調查地点では亀裂や空隙などが発達した 部分に地下水が流れている可能性が高いと考えられる.

スイゼンジノリ自生地より北に約 $100 \mathrm{~m} て ゙$ 測定した測線 2 の電気探査結果(図-8 参照)によると, 測線の中央部に 幅約 $50 \mathrm{~m}$ ，深さ約 $10 \mathrm{~m}$ から $170 \mathrm{~m}$ にわたり比抵抗の小さ い領域 $(104 \Omega \cdot \mathrm{m}$ 以下)が見られる。さらに小さい比抵抗 領域 $(50 \sim 72 \Omega \cdot \mathrm{m})$ は上部之下部に見られ，それらが連結

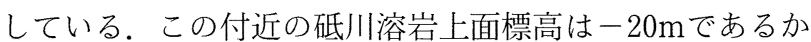
ら，上部の比抵抗值の小さい領域の地下水は測線 1 の地下 水之同じ砥川溶岩中の水脈之考えられ，下部の水脈は砥川 溶岩下の未区分洪積層の地下水と推定される。調查地区で の深度約 35 80m までに砥川溶岩が厚く分布し，その層 の上下約 $10 \mathrm{~m} は$ 多孔質であるが，中心部分は固結度が高 い. 著者らが行ったこの周辺の電気探査結果では砥川溶岩 の中心部の比抵抗值は高く, 常に連続した地層として存在 するが，図-8 のように砥川溶岩の中心部に比抵抗值の低 い部分が存在するのは稀である。砥川溶岩の下は未区分洪 積層であり，この層の地下水は熊本市の主要水源として取 水されていることより，この層の被圧地下水が砥川溶岩の 亀裂などにより砥川溶岩の上部に流出しているものと考え られる。なお，この温水機構については，更なる詳細な調 査や井戸資料などを参照して総合的に検討していきたい．

\section{5. 江津湖の湧水量と水質}

\section{1 湧水量の変動}

江津湖は, 豊富で清洌な湧水があり, 止水性の湖の性格 と流水性の河川の性格を併せ持つ河川湖である。そのため 多種多様な生物が生息し，市民の覟いの場として親しまれ ている。しかし，近年の湧水量は減少傾向にある。図-9は, 1991年12月から著者らが每月 1 回測定している涌水量調査

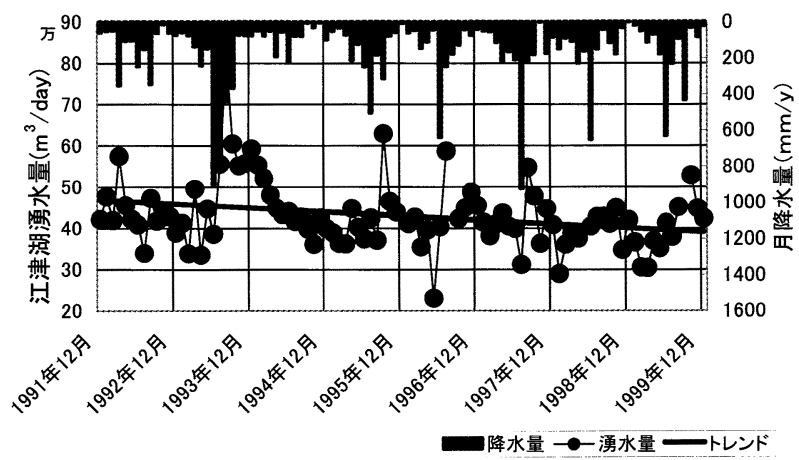

図-9＼cjkstart湧水量の経年変化

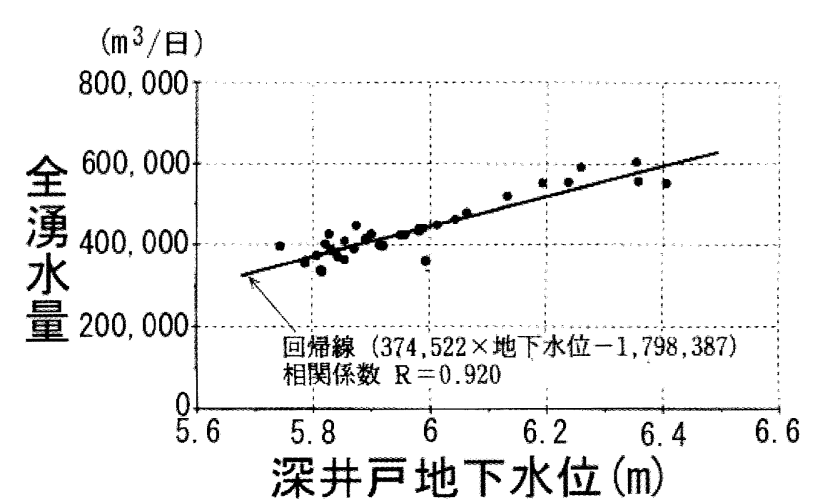

図-10＼cjkstart全湧水量と深井戸地下水位の関係図

の結果である. 江津湖には複数の河川が流入しているため, 最下流である下江津湖へ流入している河川流量を減じた値 を湧水量とした。湧水量は, 梅雨前の $3 \sim 5$ 月にかけて最 低涌水量を, 梅雨後の $8 \sim 10$ 月にかけて最高湧水量を示し ている，ここ数年は日量 40 万 $\mathrm{m}^{3}$ 前後を維持しているが, 昭和 30 年ごろの日量 100 万 $\mathrm{m}^{3}$ を越える涌水量から比べる と半分以下に減少している。また，1992 年から 1999 年の 7 年間の間に約 44 万 $\mathrm{m}^{3} / \mathrm{day}$ あったものが，約 39 万 $\mathrm{m}^{3} /$ dayになり約 $10 \%$ の減少している。熊本県・市が行った 平成 6 年度熊本地域地下水総合調査報告書においても, 1990 年から 2010 年の間に約 13\%減少すると予測している が，この予測を上回る減少率になっている，湧水量の変動 は，地下水位の変動に連動していると思われるので，N氏 邸内の井戸の砥川溶岩の帯水層まで達している深度 $35 \mathrm{~m}$ の深井戸の地下水位観測値と上江津湖の涌水量との関係を 図-10に示す.この結果，相関係数は 0.92 之高い相関を示 している23. 地下水位低下が続けば湧水量は今後も減少し つづけ, 江津湖の水生生物の衰退や水質の悪化などの要因 となる。

\section{2 江津湖の水質}

江津湖の水質は, 水前寺公園周辺加ら上江津湖にいたる 藻器掘川左岸の砂取涌水群と上江津湖左岸の神水涌水群か らの湧水によって基本的には成立している，上江津湖と中 江津を流下して，下江津湖を滞留している間に，浅い湖沼 的な特徵を水質的にも表すようになる。 とくに 5 月加ら 9 月ごろまで植物プランクトンや主に上江津湖に繁茂したオ オカナダモなどの沈水植物の光合成により，日中の表面付 近の $\mathrm{pH}$ は上昇し，9近くなることも珍しくない。また， 溶存酸素濃度も上昇し飽和溶存酸素の 2 倍以上になること あよく見られる. 同様に植物プランクトンの増殖により， 硝酸性窒素などの溶解性窒素や溶解性リンなどの栄養塩濃 度の減少が観測される。

ここでは，上江津湖左岸にある 4 か所(図-4 のNo.3〜6) の涌水水質と上江津湖上流側約 $200 \mathrm{~m}$ の左岸にある $\mathrm{N}$ 氏邸 内の浅井戸と深井戸の水質について検討した結果について 報告する．水質分析法は，上水試験方法(1993 年版)に準 


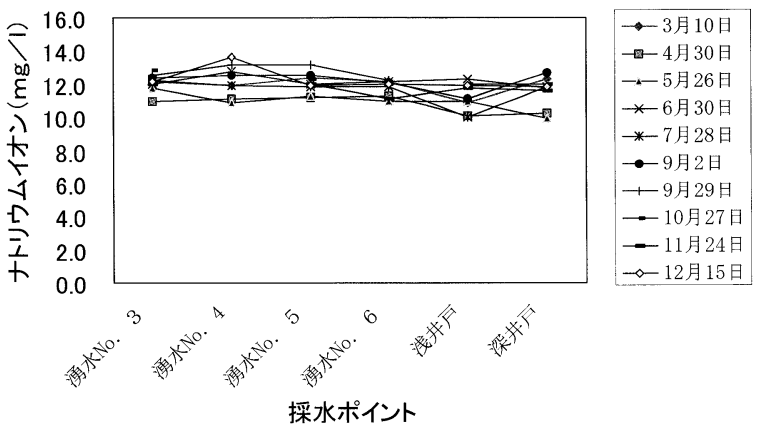

図-11 江津湖湧水と井戸水の水質(ナトリウムイオン)

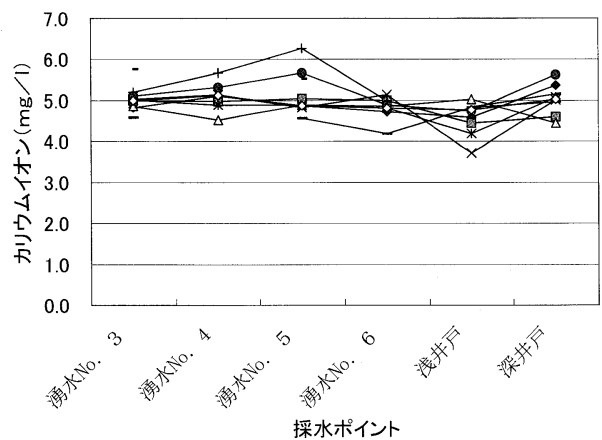

$\rightarrow 3$ 月 10 日

一눈 4 月 30 日

-6 月 30

*-7月 28 日

-9月2日

十 9 月 29 日

$\multimap 12$ 月 15 日

図-12 江津湖湧水と井戸水の水質 (カリウムイオン)

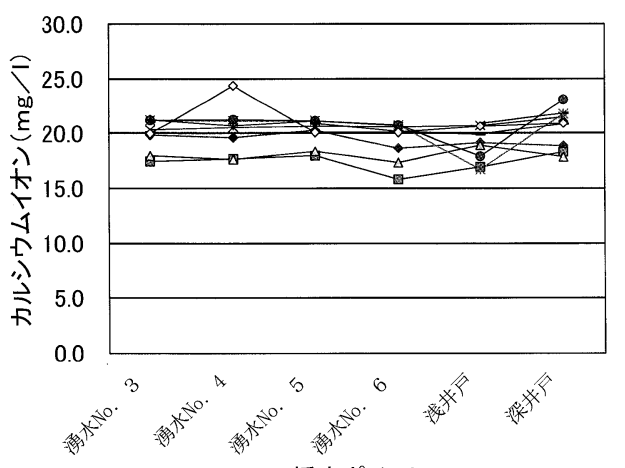

- -3 月10日

- 6 月 3 月 30 日

$\triangle-5$ 月26日

*-7月 28 日

- 9 月2日

+9 月29日

-10 月 27 日

$\longrightarrow 11$ 月 24 日

採水ポイント

図-13 江津湖湧水と井戸水の水質(カルシウムイオン)

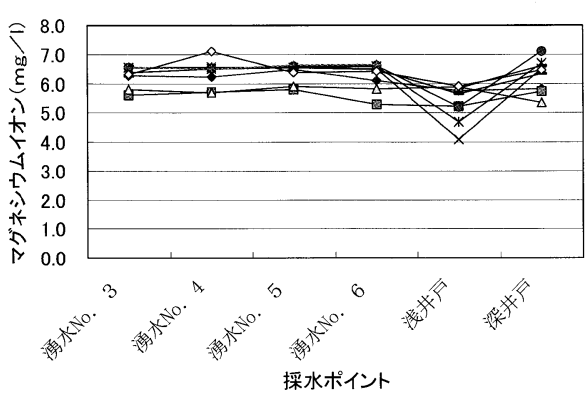

-3 月 10 日

-는-4月30日

-5 月 26 日
$-\leftarrow 6$ 月 30 日

*-7月28日

$\rightarrow-9$ 月 2 日

- -9 月 29 日

- 10 月 27 日

- 11 月 24 日

$\multimap 12$ 月 15 日

採水ポイント

図-14 江津湖湧水と井戸水の水質 (マグネシウムイオン)

拠し，アルミニウムはオキシンによる吸光光度法, 溶性ケ イ酸は，モリブデン黄による吸光光度法による．陽イオン・ 陰イオンについてはイオンクロマトグラフ法(陰イオンは サプレッサー方式による)によって測定した。なお， N氏 邸内の浅井戸の深度は地表面から約 $5 \mathrm{~m}$ の浅層地下水であ り, 深井戸の深度は $35 \mathrm{~m}$ の砥川溶岩上面に達した第二帯 水層の地下水である。年間におけるいくつかの水質变動を
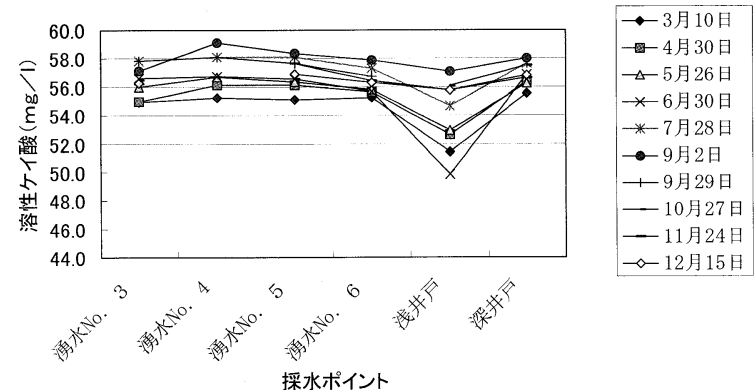

図-15 江津湖湧水と井戸水の水質(溶性ケイ酸)

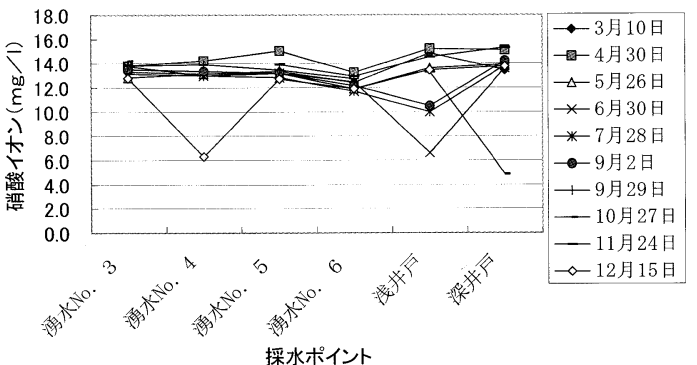

図-16 江津湖湧水と井戸水の水質 (硝酸イオン)

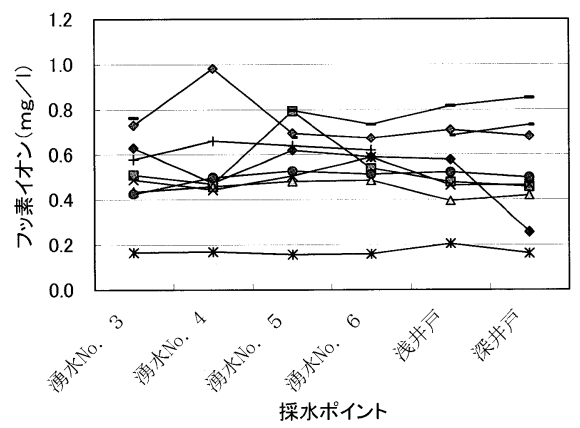

$\rightarrow$ 月 10 日 $\rightarrow-4$ 月 30 日 $\rightarrow-5$ 月 26 日 *6月30日 $\rightarrow-7$ 月 28 日 $\rightarrow 9$ 月 2 日
+9 月 29 日 - 10 月 27 日 - 11月24日 $\rightarrow 12$ 月 15 日

図-17 江津湖湧水亡井戸水の水質 (フッ素イオン)

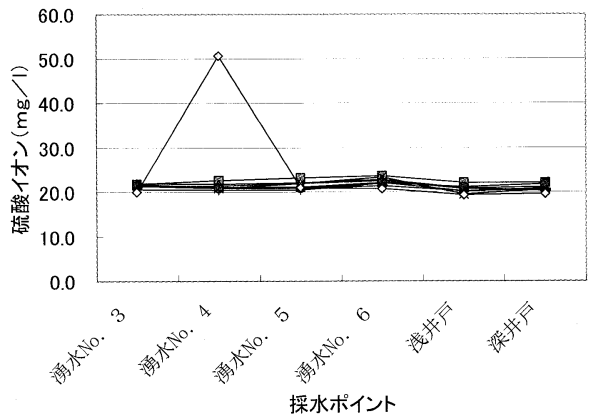

- -3 月10日 $\rightarrow-4$ 月 30 日 $\triangle 5$ 月 26 日 *6月30日 * 7月28日 - 9 月 2 日 + 9 月 29 日 - 10 月 27 日 - 11月24日

図-18 江津湖湧水と井戸水の水質(硫酸イオン)

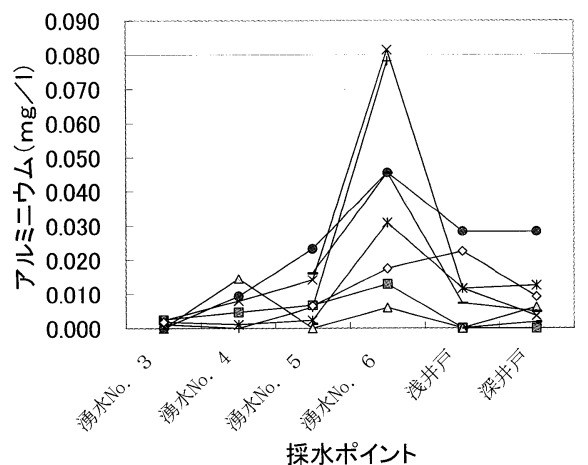

$\longrightarrow$-3月10日 궁-4月30日 $\triangle 5$ 月 26 日 *6月 30 日 *-7月28日 - 9 月 2 日 十9月29日 -10 月 27 日
-11 月24日 $\multimap 12$ 月15日

図-19 江津湖湧水と井戸水の水質 (アルミニウム) 
示したグラフを図-11〜19 に示した.

これによると, 一価陽イオン, 二価陽イオン, 硫酸イオ ンなどの主な陰イオンそして, 溶性ケイ酸については上江 津湖左岸の涌水 4 地点および浅井戸，深井戸ではほぼ同様 な水質をしており，上江津湖左岸周辺の湧水水質と上江津 湖下部の地下水水質は混合している可能性が高い。ただ, 年間における各涌水と浅井戸，深井戸の水質変動の仕方は, 項目によって異なり, ほとんど変動幅が同じものから，ア ルミニウムのように変動幅が場所によって異なるものまで あり，水質の細部についてはそれぞれ微妙に異なっている. とくに, 湧水No.3 はスイゼンジノリ自生地であり, 他の 湧水に比べて極端にアルミニウムが少ない，現在この湧水 のみにしかスイゼンジノリが存在しないのはアルミニウム に左右されている可能性ああり，アルミニウムが少ない地 下水はスイゼンジノリ自生地より北の地下約 $150 \mathrm{~m}$ の水質 に支配されている可能性が高いと推定される。

\section{6. まと め}

今回の研究で明確になったことを箇条書きすると次のよ うになる。

1. 地盤情報データベースより得られた地下水位とASO-3 および $4 / 3$ ロム地層等高線図より，上江津湖北東部の 周辺は第一帯水層と第二帯水層が混じり水前寺公園や上 江津湖に湧水している可能性が高い.

2. 国指定天然記念物スイゼンジノリ発生地周辺の地下には 幅約 $50 \mathrm{~m}$ ，深さ約 $40 \mathrm{~m}$ にわたり比抵抗の低い部分が見 られ，その一部から湧水していると考えられる。また， 同指定地より北方約 $100 \mathrm{~m}$ の地下約 $150 \mathrm{~m}$ にあ水脈があ り，そこから上部の水脈に供給している可能性が高いこ とがわかった.

3. 江津湖の湧水量は 1992 年から 1999 年の 7 年間の間に約 $10 \%$ の減少が見られ，江津湖の水質の悪化之水生生物の 衰退が懸念される.

4. 上江津湖左岸の湧水 4 地点抢よび浅井戸，深井戸の一価 陽イオン, 二価陽イオン, 硫酸イオンなどの主な陰イオ ンそして，溶性ケイ酸については，ほぼ同様な水質をし ている，浅井戸と深井戸の水質はほぼ同じであること， 測定した地点では第一帯水層と第二帯水層との間に難透 水層が欠落していることから第一帯水層と第二帯水層と が混合している可能性が高いことがわかった。

5. 国指定天然記念物スイゼンジノリ発生地の湧水は極端に アルミニウムが少ない傾向にあり，スイゼンジノリの自 生に何らかの影響を与えているもの之考えられる。

今回の研究で, 自生スイゼンジノリの湧水が特殊な地 質環境下にあることと, その周辺の水環境が悪化の状況 になり，スイゼンジノリに悪影響を与えていることがわ かった。今後，スイゼンジノリ自生地抢よびその周辺の
水質や湧水量とその湧水機構の詳細な解明とともに， ス イゼンジノリの生理生態等について研究し, 自生スイゼ ンジノリの保護に役立てたい.

\section{引 用 文 献}

1 ）清水正元(1984）：澄んだ湖をつくる，朝日選書 268, 1984.

2 ）椛田聖孝 (1998)：国指定天然記念物「スイゼンジノリ発生地」 の現状，第 1 回水環境復元全国大会報告集, pp.26-31.

3 ) 椛田聖孝 - 岡本智伸 - 小田原健 - 中園孝裕 - 菊池正武(1997)： 淡水産ラン藻，スイゼンジノリ(学名)の一般成分㧍よび培養 法に関する研究, 九州東海大学農学部紀要, 第16巻, pp.4753.

4 ）椛田聖孝・小田原健・岡本智伸 (2001)：国指定天然記念物 「スイゼンジノリ発生地」の現状とその保護活動, 第 9 回世 界湖沼会議発表論文集, Session4, pp.525-528.

5 ) 江津湖研究会 (2002)：江津湖, 第 $9 \cdot 10$ 合併号 (20周年記念号).

6 ）市川勉・星田義治・荒牧昭二郎・椛田聖孝・金子好雄(1992)： 熊本平野に扔ける湖沼の污濁機構の解明とその再生に関する 研究, 九州東海大学産業技術研究所所報, 第 8号, pp.1-8.

7 ) 中山洋・荒牧昭二郎・市川勉 - 金子好雄 $・$ 星田義治・椛田聖 孝・鈴木康夫（1994）：江津湖周辺における水理地質と水環 境,九州東海大学産業技術研究所所報, 第10号, pp.89-122.

8 ) 宮本昇・柴崎達雄・高橋一・畠山昭・山本荘毅 (1961)：阿蘇 火山西麓台地の水理地質, 地質学雑誌, Vol.68, No.800, pp.282-292.

9 ) 渡辺一徳・小野晃司(1969)：阿蘇カルデラ西側, 大峰付近の 地質，地質雑，第75巻，第 7 号, pp.365-374.

10）今西茂(1963)：熊本平野およびその周辺の地質, 熊本大学理 学部地学研究報告,第 1 号, pp.18-29.

11）籾倉克幹 (1976)：阿蘇西乃くの地下水について, 日本応用地 質学会, 昭和51年度研究発表会予稿集, pp.46-49.

12）籾倉克幹・吉川満・杉山茂・高橋宏徳 (1977)：阿蘇西乃くの 地下水涵養, 日本応用地質学会, 昭和 52 年度研究発表会予稿 集.

13）籾倉克幹 (1981)：阿蘇火砕流放出当時とその後の熊本平野の 古地図, 日本地質学会1981会講演要旨, p.90.

14）熊本市水道局 (1980)：熊本市およびその周辺の地下水につい $\tau$.

15）原田和彦・田中伸廣 (1983)：阿蘇西ろくに抢ける地下水かん 養, 土之基礎, Vol.31, No.2, pp.39-44.

16）熊本県・熊本市 (1986)：熊本地域地下水調査報告書.

17）熊本県・熊本市 (1995)：平成6年度熊本地域地下水総合調査 報告書.

18）松本幡郎 (1974）：砥川熔岩について，火山，第 2 集，第19巻, 第 1 号, pp.19-24.

19）田尻要・中山洋・荒牧昭二郎・古沢二・今泉繁良(1998)：地 盤情報データベースを用いた熊本市域に掞ける地下構造の解 明, 応用地質, Vol.39, No.4, pp.346-351.

20）斉藤林次 (1982)：阿蘇火山西麓の地下地質, $\mathrm{S} \cdot \mathrm{G}$ 技報, No.2, pp.1-5.

21）渡辺一徳・籾倉克幹・鶴田孝三 (1979)：阿蘇カルデラ西麓の 活断層群之側火口の位置, 第四紀研究, 第18巻, 第 2 号, pp.8999.

22）島裕雅・梶間和彦・神谷英樹編 (1995)：建設・防災・環境の ための新しい電気探査法 比抵抗影像法, 古今書店.

23）市川勉(1998)：熊本地域に打ける降雨と地下水位, 涌水の関 
係について（ I ) 一湧水量と地下水位一, 水利科学, No.239, pp.1-7.

24）市川勉(1999）：熊本地域に打ける降雨と地下水位，涌水の関 係について (II) 一蒸発，水田涵養を考慮した降雨と涌水の関 係一, 水利科学, No.249, pp.67-87.

25）桐山貴文・市川勉・星田義治(1998）：蒸発を考慮した地下水 位と涌水量の関係, 九州東海大学工学部紀要, No.24, pp.8189.

26）塚本一也・市川勉・桐山貴文(2000)：都市部湖沼におけるビ
オトープの評価一熊本市水前寺・江津湖を例として一，九州 東海大学工学部紀要, No.26, pp.51-58.

27）北島佳房・市川勉(2000)：熊本地域における地下水涵養の効 果について, 九州東海大学工学部紀要, No.26, pp.29-33.

28）桐山貴文・市川勉・星田義治(2000)：タンクモデルによる熊 本地域における地下水位の推定,土木学会水工学論文集, 第 44 巻, pp.223-228.

（2002年 5 月 7 日受付， 2002 年11月13日受理）

\title{
Studies on the Groundwater Environment of Lake Kami-Ezu for the Conserva- tion of Suizenjinori(Aphanothece sacrum (Sur.)Okada) in Kumamoto City
}

\author{
Shojirou ARAMAKI, Yoshio KANEKO, Tsutomu ICHIKAWA, Chinobu OKAMOTO and \\ Kiyotaka KABATA
}

\begin{abstract}
Suizenjirori (Aphanothece sacrum (Sur. )Okada) is a one of freshwater unicellular Cyanobacterium. However, there is little academic paper with regard to Aphanothece sacrum (Sur. ) Okada, because of the difficulty getting it as experimental material. The purpose of this paper is to describe the groundwater environment for the conservation of Aphanothece sacrum (Sur. ) Okada . Recently, spontaneous Suizenjinori has faced to the crisis of extinction by decrease of water flow and water pollution with the city development. The resistivity image profiling obtained from electric prospecting, stratum division picture with ground information database, water quantity and water examination were investigated to get the foundations data for Suizenjinori conservation. The spring rate of Lake Ezu area was ca. $400,000 \mathrm{~m}^{3} / \mathrm{d}$ and decreased about $10 \%$ of the water flow during the experimental period (from 1992 to 1999). There are groundwater come out from three aquifers i.e. most upper aquifer and Togawa lava upper and lower sediment layers in Lake Ezu. It is considered to mix the groundwater of Togawa lava layer and its upper sediment layer in the neighborhood of Lake Ezu. It is marked by a lower concentration of aluminum in Suizenjinori pond than the other spring pond. It is regarded to influence the basement water under Togawa lava to inhabit Suizenjinori.
\end{abstract}

Key words : Suizenjinori, groundwater, resistivity image profiling, water examination 